Proceedings of the Institution of
Civil Engineers
Transport 159
February 2006 Issue TRI
Pages I5-24
Paper I3948
Received 17/08/2004
Accepted 23/09/2005
Keywords:
embankments/environment/roads \&
highways
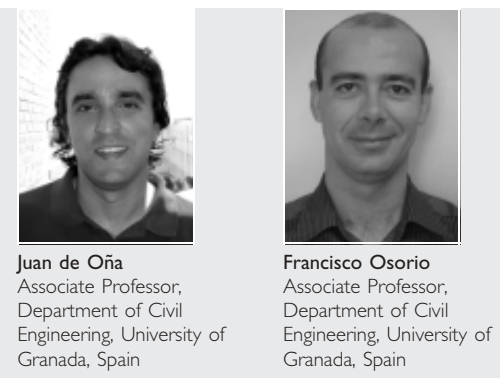

\title{
Using waste to reduce slope erosion on road embankments
}

\author{
J. de Oña and F. Osorio
}

Urban waste may be used to reduce slope erosion of highway embankments. Whereas different kinds of compost have been tested in the USA for highway revegetation, sewage sludge has been used only for agricultural purposes. This paper presents the results of research carried out in order to study the viability of the application of sewage sludge compared with compost. Test areas measuring $4 \mathrm{~m} \times \mathbf{5} \mathrm{m}$ were constructed on a new highway embankment with $2: I$ and $3: 2$ side slopes in the south of Spain. Crop cover and erosion were evaluated for plots with application of three dosages of compost and three dosages of sludge. Also, the costs of the proposed application are analysed. This treatment costs, on average, $\mathbf{0 . 2 4} \%$ of the budget for new roads infrastructure, and reduces soil loss by up to $30 \%$ on average. Based on these results, compost and sludge can be successfully used to reduce slope erosion on highway embankments. However, standards and specifications are required for their routine application.

\section{ROAD CONSTRUCTION AND EROSION}

The construction of new highways and the improvement of existing ones in order to facilitate access between urban settlements has been a constant demand made by society. These investments also have economic, social and environmental objectives (e.g. integration, cohesion and geographical equilibrium; reduction in energy consumptionn, travel time, traffic congestion and noise pollution). Nevertheless, road construction also has negative environmental effects. It destroys the natural environment through which the roads pass: a loss of natural equilibrium, a loss of cover crop, an increase in soil erosion, etc.

Since the Brundtland Report ${ }^{1}$ in 1987 , sustainable development has been the most important philosophy in almost all developed countries, and especially in the European Union (EU). Environmental issues have been highlighted in numerous documents and in recent regulations. ${ }^{2}$ So road construction is complemented by rigorous environmental impact studies and correction measures.

Highway planning and project design of road embankments are no longer limited by the traditional problems of stability.

Landscape integration, vegetation establishment and reduction of soil loss caused by erosion are design parameters that are as important as geotechnical ones. ${ }^{3}$ Nowadays, engineers must justify their decisions based on a much wider set of conditions, where environmental recovery and sustainable development determine the implementation of a project.

Degradation caused by erosion is one of the main causes of slope instability on road embankments. ${ }^{4}$ Factors that influence erosion are: climate aggression; the nature of the ground; the topographic relief and its slope, length and watershed form; and the natural or implanted cover crop. Some of these factors, such as the cover crop, nature of the ground or bank slope, can be worked on, but others cannot be modified, because they are characteristic of the area where the infrastructure is built. This is the case for the climate.

There are many different measures to take against soil loss caused by erosion in road embankments: ${ }^{4-6}$ erosion control nets, open-weave geotextiles, geosynthetic mattings, erosion control blankets, loose mulches, hydromulches and chemical soil binders. Most are designed to absorb the kinetic energy of rainfall by minimising its contact with the soil and reducing water velocity.

Vegetation has several favourable effects in protecting embankments from erosion: cover crop blocks and retains water coming from rainfall, and splash erosion decreases; and soil permeability and the infiltration rate are greater in soils with plants than in soils without them. ${ }^{7}$ These effects, together with evapotranspiration, permit the reduction of free water on the terrain surface, and therefore protect the slope from surface runoff. Other effects include: modification of mechanical properties and soil fastening thanks to the roots, which create an intimately linked fibre frame; protection from traffic and being stepped upon, as it absorbs impact; and isolation, because a microclimate that reduces temperature and humidity variations is created on the soil surface. Thus there is a decrease in the natural weathering process.

Plants have a very important role in erosion control and side slope stabilisation. However, the characteristics of embankments are not usually suitable for plants, as materials are selected according to their geotechnical characteristics. Furthermore, construction sites with an arid climate present more problems for revegetation.

Timely vegetation establishment is extremely critical after roadway construction is completed. If grass fails to grow, soil is 
washed away, and erosion begins to threaten the paved surface of the roadway. Vegetation establishment is the final phase of any roadway construction project. ${ }^{6}$ When a project nears completion, topsoil is bladed over the subgrade material. Grass seed is then hydroseeded, and a mulch or erosion blanket is applied over the seedbed.

Quality topsoil is essential for adequate grass cover. Unfortunately, soil, whether stockpiled on site or obtained from other sources, is often void of the organic matter needed for proper grass establishment. ${ }^{6}$ Often, topsoil is treated with fertilisers to improve its agronomic properties.

\section{ROAD AND URBAN WASTE: A PROMISE FOR THE FUTURE}

A serious worldwide concern is the overproduction of human wastes. New problems are starting to arise in the management of these wastes, mainly because of storage difficulties. Traditional solutions such as dumping sites and incineration are questioned, for several reasons: ${ }^{8,9}$ dumping sites are dangerous because they can affect subsoil water, and it is difficult to control waste evolution as well as the sealing system used; and incineration is an emission source, and may be very polluting in some cases.

Therefore these waste management measures are being restricted by EU directives, which have already been included in national legislation. These measures have prompted the research for new feasible environmental solutions in the EU, even if society has to incur some recycling costs.

The EU has been working towards recycling materials for use on roads and highways for a number of years. Clients should accept recycled materials in civil engineering as long as the engineering characteristics of these materials are the same as those of conventional materials. ${ }^{10,11}$ Also, they have to be nonvolatile, volumetrically stable products and non-noxious leached products.

Many waste products have been researched, and some of them have been already accepted in engineering ${ }^{9-11}$

(a) road building wastes: materials from road surface layers, quarry oversize and from mineral dust of bituminous mixture factories

(b) industrial wastes: thermal power station ashes, iron and steel industry ashes and mine spoil, mainly from coal.

(c) urban wastes: urban incinerator ashes, used tyres, demolition waste, used engine oils, waste plastic and glass.

But waste management problems are becoming worse in urban environments because of the high population density. Sludge and compost are generated in treatment lines as the result of operational wastewater treatment plants and recycling and composting plants all over the world, but they are not reused in many countries. Sludge is a by-product of the sewage treatment process, and compost is defined as decomposed organic material (e.g. organic domestic rubbish, grass and leaves).

There is considerable experience of sludge utilisation in agriculture in Europe and the USA. ${ }^{12,13}$ There is also some experience in the USA of compost utilisation in road construction for reducing runoff and erosion. ${ }^{6,14-16}$ Nevertheless, sludge is not reused when attempting to reestablish vegetation on road embankments.

These two problems (erosion of road embankments and urban waste management) seem to be unrelated, but if the fertilising capacity of sludge ${ }^{12}$ and compost ${ }^{15}$ and the need to improve the agronomic properties of highway embankments materials are considered together, it is clear that they are related, and their combination could partially solve both problems. Fertilisation from urban waste helps in the growth of a cover crop, which in turn reduces erosion.

Therefore urban waste management could have roads as one of its major customers. ${ }^{13}$ This is a new domain, barely analysed until now from a road engineering perspective, and therefore its application possibilities have to be researched.

\section{OBJECTIVES AND PHASES}

The present research was undertaken to study the viability of the use of sludge and compost for road embankment revegetation. The objectives were to

(a) assess the plant growth in the plantings and analyse the technical and economic viability for future work

(b) study the influence of design parameters on embankment in terms of revegetation criteria, not just mechanics criteria

(c) establish the benefits obtained by soil fixation, assessing erosion caused by atmospheric agent action

(d) compare the results and costs for compost and sludge applications.

The research methodology fell into four main phases

(a) study and analysis of fundamental variables

(b) experiment design and execution

(c) process follow-up and control

(d) analysis of results.

\section{VARIABLES}

During the first phase, the main objective was to identify and define the variables that have some influence on the research, in order to optimise the tests to be carried out. The main variables considered were
(a) location and orientation
(b) embankment side slope
(c) characteristics of soil, sludge and compost used in the embankment
(d) sludge and compost dosages
(e) species selection
$(f)$ experimental plot dimensions
(g) planting characteristics.

These are considered below.

\section{I. Location and orientation}

The experiment was carried out in a semi-arid environment, which is characterised by high climate erosivity-infrequent but intense rainfall-and limited vegetation, where erosion processes have a big impact. 
The research site was located on a south-east-facing slope of a highway embankment in the waste recycling and composting plant of Gádor in Almeria, in the south of Spain (Fig. 1). This location ensured complete access control to the area and low traffic, and minimised any risks during the tests.

This area is situated between the Gádor Mountains, located to the west, and the Alhamilla Mountains, located to the east. It is an area of many ravines and dry riverbeds. The climate is typically dry Mediterranean. The average annual precipitation is $219 \mathrm{~mm}$, concentrated during winter and autumn and at the beginning of spring. Winds come from the coast area, the westsouth-west, but a large part of the terrain is protected by the Gádor Mountains. Wind from the east is also frequent, especially in summer, and it is so hot that it produces major dehydrations. The wind from the north enters this area and produces temperatures near $0^{\circ} \mathrm{C}$ during some of the winter months. Maximum and minimum temperatures registered during the research were $40^{\circ} \mathrm{C}$ and $3.5^{\circ} \mathrm{C}$, with an average relative humidity of 66\% (Fig. 2).

\subsection{Embankment side slope}

The standard side slopes are $3: 2$ and $2: 1$; these are the most widely used in road embankments because of geotechnical factors.

The first $\left(33 \cdot 7^{\circ}\right)$ complies with enough security requirements for a great variety of soil types, and it reduces the total surface of occupation and the final earth-moving volume. The second $\left(26 \cdot 6^{\circ}\right)$ is used mainly for security requirements with very loose unconnected materials that have very little internal friction, or for environmental integration reasons.

Table 1 shows the internal friction angle and cohesion of

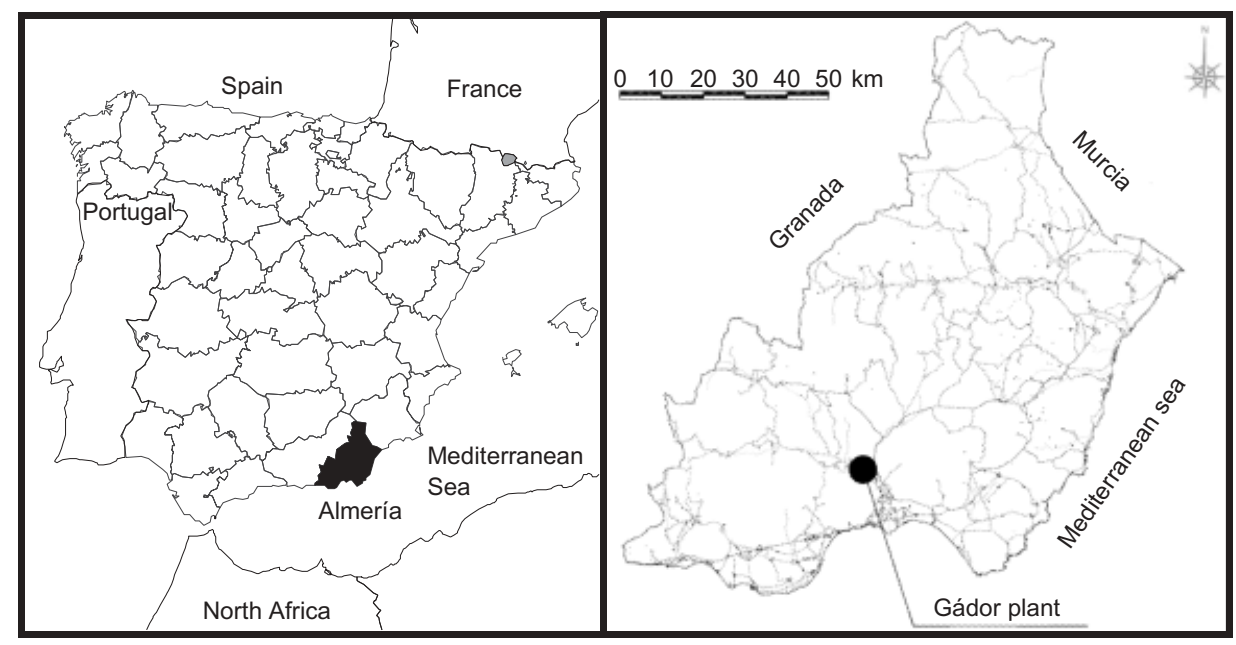

Fig. I. Location of Gádor (Almería, Spain) solid waste treatment plant

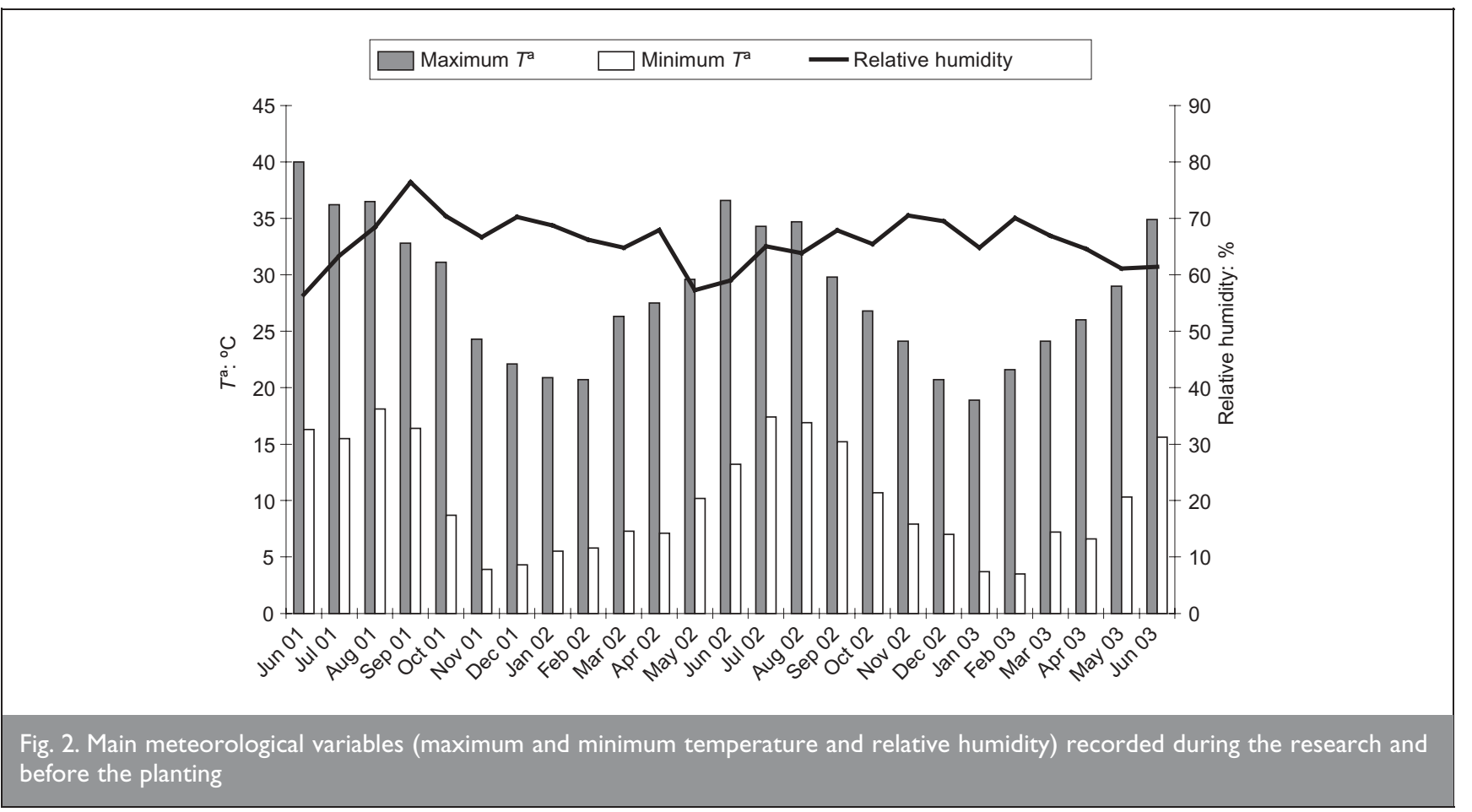




\begin{tabular}{|c|c|c|c|}
\hline \multicolumn{4}{|l|}{ Soil classifications } \\
\hline & $\begin{array}{l}\text { Group and } \\
\text { subgroup }\end{array}$ & \multicolumn{2}{|c|}{ Description } \\
\hline ASTM & SM & \multirow{2}{*}{\multicolumn{2}{|c|}{$\begin{array}{l}\text { Silty sands, sand-silt mixtures. More than } 50 \% \text { passes } \\
\text { No. } 4 \text { sieve. More than } 50 \% \text { retained on No. } 200 \\
\text { sieve } \\
\text { Materials consisting predominantly of stone fragments } \\
\text { or gravel, either with or without a well-graded soil } \\
\text { binder. These soils have high strength (friction angles } \\
\text { higher than } 34^{\circ} \text { ) }\end{array}$}} \\
\hline AASHTO & $A-I-a$ & & \\
\hline \multicolumn{4}{|l|}{ Geotechnical parameters } \\
\hline $\begin{array}{l}\text { Internal friction angle } \\
\text { Cohesion }\end{array}$ & \multicolumn{3}{|c|}{$\begin{array}{l}42 \cdot 20^{\circ} \\
5 \mathrm{t} / \mathrm{m}^{2}\end{array}$} \\
\hline \multicolumn{4}{|l|}{ Other parameters } \\
\hline & \multicolumn{2}{|c|}{ Obtained values } & Limits in Spain* \\
\hline Organic material content & & $0 \cdot 32 \%$ & $<2 \%$ \\
\hline Gypsum content & & $0.41 \%$ & $<5 \%$ \\
\hline Other soluble salt content & & $0.42 \%$ & $<1 \%$ \\
\hline Liquid limit & & $30 \cdot 2 \%$ & $<65 \%$ \\
\hline
\end{tabular}

embankment fill materials. As the internal friction angle is $42 \cdot 2^{\circ}$ either slope could be used.

The test were carried out on both slopes to compare the influence of the embankment slope on the results.

\subsection{Characteristics of soil, sludge and compost used in the embankment}

Complete analyses of the soil used in the embankments were carried out. Table 1 shows the soil classification, geotechnical and other parameters. The embankment fill materials were classified as silty sands or sand-silt mixtures (SM), using the ASTM classification, and materials consisting predominantly of stone fragments or gravel, either with or without a well-graded soil binder (A-1-a), using the AASHTO classification.

The analyses (organic material content, gypsum content, other soluble salt content and liquid limit) show that this soil is suitable for use in embankment cores in Spain ${ }^{17}$ (Table 1). However, its agronomic characteristics are very poor, as shown in Table 2.

Complete analyses of the agronomic parameters of sludge and compost were made to assess their fertilising capacity (Table 2) and to check their heavy metal and microbiological parameters.

Table 3 shows heavy metals in the soil, sludge and compost samples. Sludge presents higher values for copper, zinc, mercury and chromium, and compost presents higher values for cadmium, nickel and lead.

No current regulations about heavy metal limits exist in the EU for the application of sludge or compost in road embankments. In the EU these biosolids have been used only for agricultural purposes. So agricultural regulations have been taken into account as reference.

Table 3 shows that all the heavy metal limits for sludge are higher than those for compost. So the regulations are more restrictive for compost than for sludge application in agriculture. If only sludge regulation ${ }^{18}$ is considered, none of the values (sludge or compost) exceed the threshold marked by legislation for heavy metal pollution. If compost regulation ${ }^{19}$ is considered, none of the values exceed the threshold marked by legislation except for cadmium concentration.

However, some US Departments of Transportation that have used compost for road embankment revegetation (e.g. Texas) have established heavy metal limits for 'uncontrolled' compost use as a soil amendment. ${ }^{6}$ Table 3 shows these limits; all of them are higher than those obtained for the materials used during this research.

\subsection{Sludge and compost dosages}

Seven plots were used for each of the side slopes $(3: 2$ and $2: 1$ ). Table 4 shows the dosage rate for each plot. For sludge 60,80 and $100 \mathrm{t} /$ ha were used-that is, an average thickness of $4 \cdot 72,6 \cdot 30$ and $7 \cdot 87 \mathrm{~mm}$ respectively; for compost 40,60 and $80 \mathrm{t} /$ ha were used, an average thickness of $2.33,3.49$ and $4.65 \mathrm{~mm}$ respectively.

Sludge dosages were adopted on the basis of previous work carried out in the agricultural domain. ${ }^{12}$ of course, the objectives in these studies took into account protection against 


\begin{tabular}{|c|c|c|c|}
\hline Parameter & Soil & Sludge & Compost \\
\hline Moisture content: \% & 1.97 & 75.85 & 6.03 \\
\hline Real density: g/ml & $2 \cdot 76$ & $1 \cdot 27$ & $1 \cdot 72$ \\
\hline Apparent density: $\mathrm{g} / \mathrm{ml}$ & $1 \cdot 38$ & 0.54 & 0.46 \\
\hline $\mathrm{pH}$ & 8.61 & $7 \cdot 26$ & 6.74 \\
\hline Organic matter: \% & 0.32 & 9.92 & 34.43 \\
\hline Dry matter: \% & 98.03 & $24 \cdot 15$ & 93.97 \\
\hline Conductivity: $\mu \mathrm{s} / \mathrm{cm}$ & $4 \cdot 20$ & 11.59 & 30.9 \\
\hline Humic extract: \% & 0.06 & $3 \cdot 28$ & $|8.5|$ \\
\hline Humic acids: \% & 0.02 & 1.06 & 9.83 \\
\hline Fulvic acids: $\%$ & 0.04 & $2 \cdot 22$ & 8.99 \\
\hline $\mathrm{C}: \mathrm{N}$ ratio & 4.95 & $2 \cdot 26$ & 12.69 \\
\hline Iron: mg/kg & $2 \cdot 00$ & 106.57 & $222 \cdot 4$ \\
\hline Total nitrogen: $\mathrm{mg} / \mathrm{kg}$ & $650 \cdot 98$ & 99151.9 & 10965.7 \\
\hline Nitrogen (nitric): mg/l & $10 \cdot 75$ & $<0.5$ & $<0.5$ \\
\hline Nitrogen (ammoniacal): mg/l & $5 \cdot 18$ & 378.47 & 210.47 \\
\hline Phosphorus $\left(\mathrm{P}_{2} \mathrm{O}_{5}\right): \mathrm{mg} / \mathrm{l}$ & 6.84 & 100.63 & $<1.88$ \\
\hline Potassium $\left(\mathrm{K}_{2} \mathrm{O}\right): \mathrm{mg} / \mathrm{l}$ & $20 \cdot 8$ & $377 \cdot 50$ & $4248 \cdot 8$ \\
\hline Sulphate: $\mathrm{mg} / \mathrm{l}$ & 533.98 & 4376.46 & 4234.89 \\
\hline Calcium (CaO): mg/l & 98.9 & $315 \cdot 6$ & $4036 \cdot 9$ \\
\hline Magnesium (MgO): mg/l & $122 \cdot 8$ & $527 \cdot 1$ & $1|54 \cdot|$ \\
\hline Sodium: $\mathrm{mg} / \mathrm{l}$ & $654 \cdot 1$ & $601 \cdot 5$ & 4228 \\
\hline
\end{tabular}

\begin{tabular}{|c|c|c|c|c|c|c|c|c|}
\hline & & Cadmium & Copper & Nickel & Lead & Zinc & Mercury & Chromium \\
\hline Soil & & $2 \cdot 28$ & $<1$ & 2.52 & 9.93 & $<0.5$ & 0.21 & 4.19 \\
\hline \multirow[t]{2}{*}{ Sludge } & Value & 3.82 & $230 \cdot 50$ & $19 \cdot 10$ & 38.66 & 577.00 & 8.59 & $23 \cdot 23$ \\
\hline & EU limit* & 40 & 1750 & 400 & 1200 & 4000 & 25 & 1500 \\
\hline \multirow[t]{3}{*}{ Compost } & Value & $15 \cdot 23$ & 16.78 & $67 \cdot 66$ & $118 \cdot 11$ & 149.59 & $|.8|$ & $12 \cdot 25$ \\
\hline & EU limit & 3 & 450 & 120 & 150 & 1100 & 5 & 270 \\
\hline & US limitf & 85 & 4300 & 420 & 840 & 7500 & 57 & 3000 \\
\hline
\end{tabular}

\begin{tabular}{|c|c|c|c|c|c|c|c|}
\hline Slope & Sludge: $t / h a$ & Compost: t/ha & Plot number & Slope & Sludge: t/ha & Compost: t/ha & Plot number \\
\hline \multirow[t]{7}{*}{$2: 1$} & 0 & 0 & 2IBase & $3: 2$ & 0 & 0 & 32Base \\
\hline & 100 & 0 & $21 S 100$ & & 100 & 0 & $32 S 100$ \\
\hline & 80 & 0 & 215080 & & 80 & 0 & 325080 \\
\hline & 60 & 0 & 215060 & & 60 & 0 & $32 S 060$ \\
\hline & 0 & 80 & $2 \mathrm{IC0} 00$ & & 0 & 80 & $32 C 080$ \\
\hline & 0 & 60 & $21 \mathrm{C} 060$ & & 0 & 60 & $32 C 060$ \\
\hline & 0 & 40 & $21 \mathrm{CO} 40$ & & 0 & 40 & $32 C 040$ \\
\hline
\end{tabular}

the same negative effects as considered in the current work. Compost dosages were adopted on the basis of treatment cost, which should be approximately the same as that of the sludge treatment.

Both treatments were applied directly to the surface of the embankment slope; no topsoil was used.

\subsection{Species selection}

Species were selected using biotechnical and environmental criteria and phytosociological considerations. Autochthonous species of local plants were selected. There was a large presence of wild plants near the Gádor plant that had shown good behaviour under adverse situations.

Several species were selected to analyse the growth capacity of each one, and to test different procedures in their application: esparto grass (Stipa tenacissima), thyme (Thymus capitatus), genista (Genista umbellata) and broom (Retama monosperma).

\subsection{Experimental plot dimensions}

Each test set-up consisted of seven adjacent test plots measuring $4 \mathrm{~m} \times 5 \mathrm{~m}$ for each one of the slopes $(3: 2$ and $2: 1$ side slopes). The dimensions were chosen on the basis of the 
kind of vegetal species selected, the number of plants, and the working conditions needed.

\subsection{Planting characteristics}

There were two different planting processes.

(a) Hydroseeding was used for esparto and thyme. Planting dosage was $2.5 \mathrm{~g} / \mathrm{m}^{2}$ for each species and a previous shelling was made before applying the seeds. The total quantity of seed was $700 \mathrm{~g}$, taking into account the two series of seven plots and the $20 \mathrm{~m}^{2}$ of surface of each plot

(b) Manual planting was applied for genista and broom. The planting frame was $100 \mathrm{~cm} \times 100 \mathrm{~cm}$ and planting was triangular (Fig. 3). In this way, no plant could have another one of its own species beside it. The total number of plants used was 20 (10 of each species) per plot. The total was 140 units of genista and 140 of broom.

\section{EXPERIMENTAL DESIGN AND EXECUTION}

The resources and procedures used during the experiment were the same as those that are available during highway construction. Thus the experiment could be reproduced on any real construction site.

Parcels were prepared on the embankment of the road that connects the selection and sorting warehouse with the fermentation and purification warehouse (Fig. 4).

Once the plots were made, sludge and compost were applied

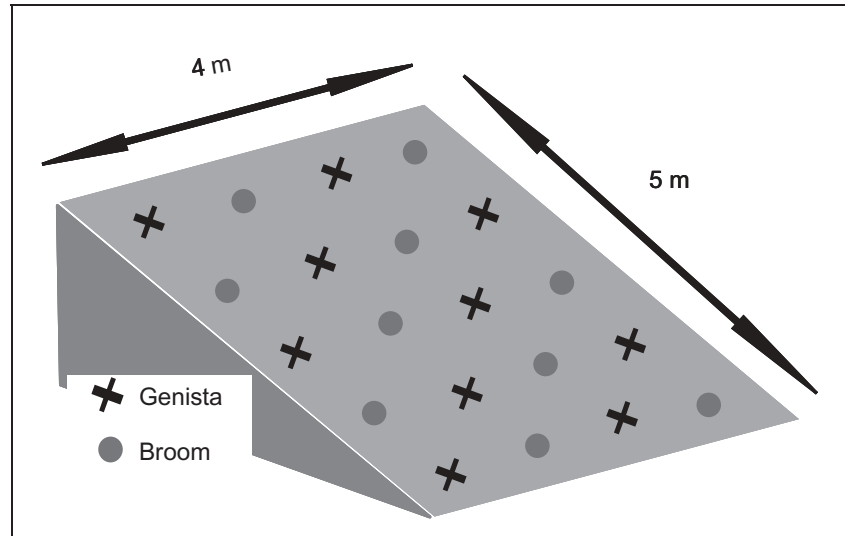

Fig. 3. Plot dimensions and planting

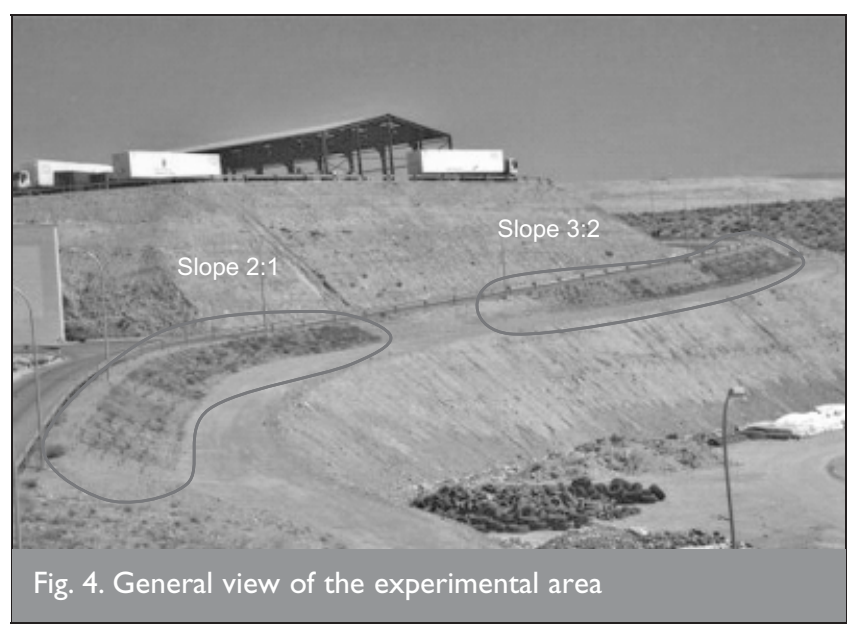

manually without any kind of cultivating (e.g. by rotovating) prior to the application. First of all, dehydrated sludge (moisture content $75 \cdot 85 \%$ ) was put in place. It was a viscous and plastic material that was difficult to handle. Later, the same was done with compost. Compost was easily distributed because it is a granular material, lacking cohesion, and loose when poured.

As mentioned above, two species were planted manually and another two by hydroseeding machine. As manual planting required stepping on the embankment slope, broom and genista were planted first, and later esparto and thyme were hydroseeded. The only maintenance was irrigation during the first three weeks after sowing, which is the usual treatment during road construction.

\section{PROCESS FOLLOW-UP AND CONTROL}

From the moment of plantation, in October 2001, a follow-up of vegetation species took place. Various parameters were measured.

(a) Plant rooting. For the two species planted manually, the survival rate (percentage of plants still alive) was recorded weekly.

(b) Plant growth. For the two species planted manually, growth percentage was recorded weekly.

(c) Plant germination. Fortnightly, germinated plants per $\mathrm{m}^{2}$ were counted for thyme and esparto.

(d) Colonisation by other species. Each month colonising plants per $\mathrm{m}^{2}$ were counted (i.e. species that had not been planted, but had developed without control).

(e) Crop cover per plot. This was measured taking a digital picture of each of the analysed plots.

$(f)$ Erosion estimation. Erosion was studied using the Universal Soil Loss Equation, ${ }^{14}$ which has been considered the base for other, later formulations and is recognised as the one that best approximates the physical phenomenon.

\section{RESULTS}

The main results of the last measurement in June 2003 are shown in Figs 5 and 6. The results of plots where neither sludge nor compost was applied (base treatment) are selected for comparisons of treatments for each side slope (plots 21Base and 32Base).

Relative percentage cover for the $2: 1$ side slope is shown on the left-hand side of Fig. 5 for each treatment. Relative percentage cover is the ratio of the vegetative percentage cover for a particular treatment within an experimental plot to that of the base treatment. The largest vegetative percentage cover was for the treatment with a compost dosage of $80 \mathrm{t} / \mathrm{ha}$ (plot 21C080), and the smallest vegetative percentage cover was for the base treatment (plot 21Base).

For the $2: 1$ side slope plots all treatments with sludge or compost showed higher vegetative cover than the base treatment. Plot 21Base showed a $12 \cdot 2 \%$ vegetative percentage cover. Sludge treatment showed, on average, a 15.8\% vegetative percentage cover: that is, sludge treatment increased vegetative cover by up to $30 \%$ on average. Compost treatment showed, on average, an 18.8\% vegetative percentage cover: that is, compost treatment increase vegetative cover by up to 


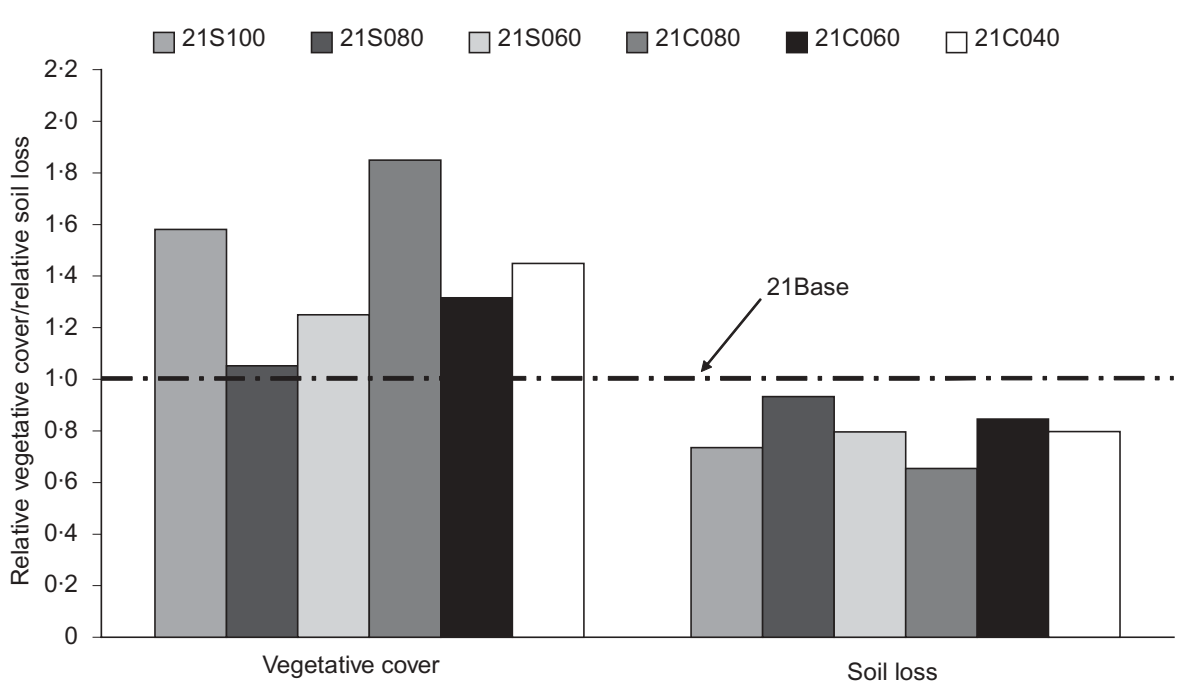

Fig. 5. Relative vegetative cover and soil loss for 2 : I side slope

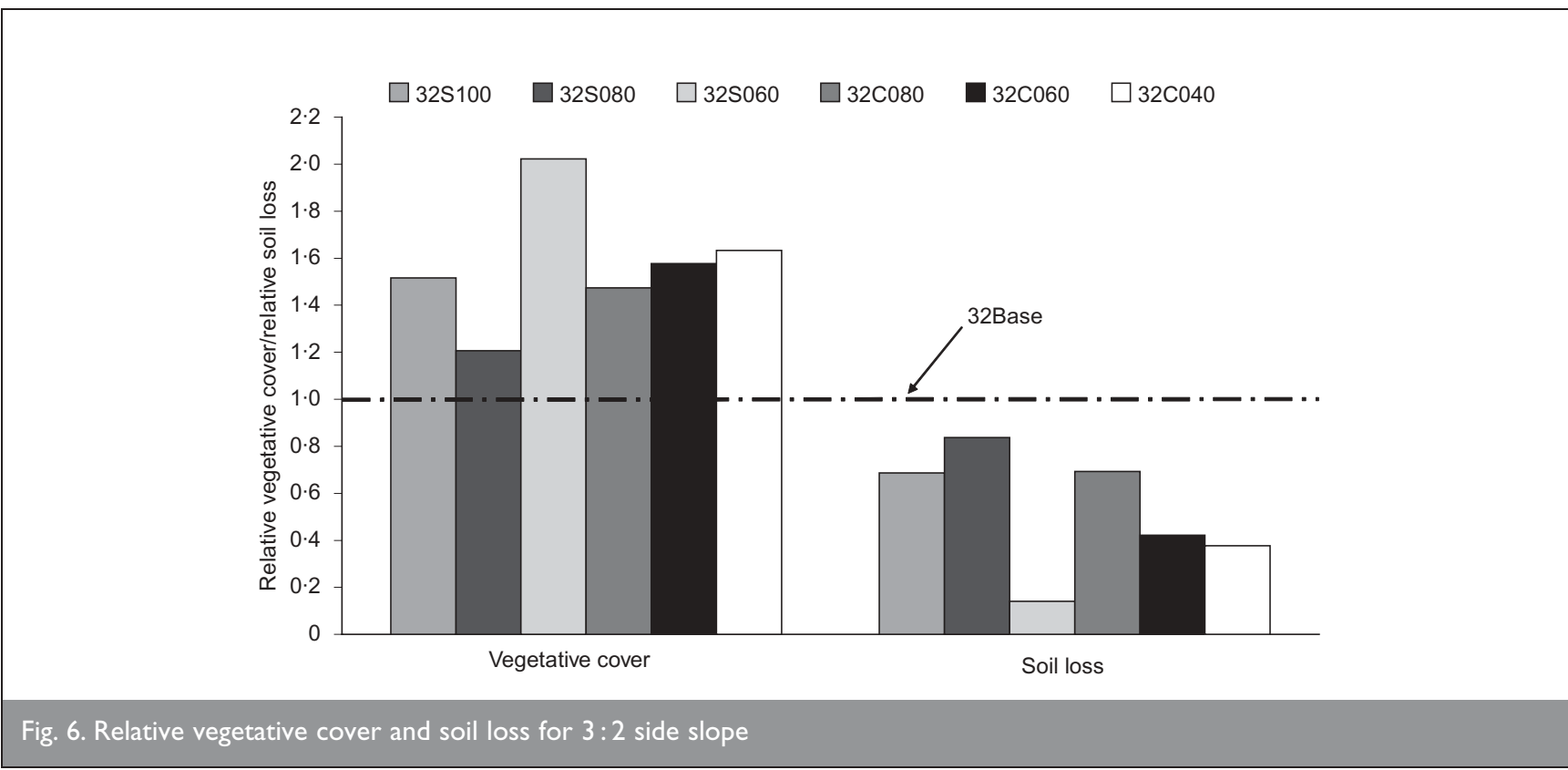

$54 \%$ on average. So, for this slope, compost treatment presented a slightly better performance than sludge treatment.

The relative percentage cover for the $3: 2$ side slope is shown on the left-hand side of Fig. 6 for each treatment. The largest vegetative percentage cover was for the treatment with a sludge dosage of $60 \mathrm{t} / \mathrm{ha}$ (plot 32S060), and the smallest vegetative percentage cover was for the base treatment (plot 32Base).

As for the other side slope, for the $3: 2$ side slope plots all treatments with sludge or compost showed higher vegetative cover than for the base treatment. Plot 32Base showed a $25 \cdot 3 \%$ vegetative percentage cover. Sludge treatment showed, on average, a $41 \cdot 1 \%$ vegetative percentage cover: that is, sludge treatment increased vegetative cover by up to $58 \%$ on average.
Compost treatment showed, on average, a $39 \cdot 6 \%$ vegetative percentage cover: that is, compost treatment increased vegetative cover by up to $56 \%$ on average. For this slope both treatments presented approximately the same performance.

Vegetative cover was higher on the $3: 2$ side slope than on the $2: 1$ side slope, essentially because of the presence of colonising species. Natural colonisation by other species was denser on the $3: 2$ side slope. This seems to be due to the fact that this embankment was closer to the natural vegetation (Fig. 4); dependence on slope cannot be inferred from these data.

For the $2: 1$ side slope, the compost and sludge plots with higher dosages (plots 21S100 and 21C080) presented greater values of crop cover. It is not possible to obtain the same results for the $3: 2$ side slope because of the colonising species. 
For the $2: 1$ highway embankment increased sludge and compost dosage implies less soil loss (Table 7). In this case, and because of the colonising species, the same cannot be inferred for the $3: 2$ side slope plots (Table 7). Nevertheless, for both embankments, all plots present less soil loss by erosion than the reference plots (21Base and 32Base).

where $A$ is the soil loss ( $\mathrm{t} /$ ha per year), $R$ is the rainfall erosivity index $\left(\mathrm{J} / \mathrm{cm} \div \mathrm{m}^{2} / \mathrm{h}\right), K$ is the soil erodibility factor $\left(\mathrm{t} / \mathrm{m}^{2}\right.$ per $\mathrm{h} \div \mathrm{ha} / \mathrm{J}$ per $\mathrm{cm}$ ), $L$ is the slope length (nondimensional), $S$ is the slope factor (non-dimensional), $C$ is the cropping factor (non-dimensional), and $P$ is the conservation practice factor (non-dimensional).

The Food and Agriculture Organisation of the United Nations has developed experimental formulations for determining all these factors. ${ }^{21}$ Several studies have adapted this formulation to the particular climate conditions in Spain. ${ }^{22,23}$ Rainfall erosivity, soil erodibility, slope length and conservation practice factors were kept constant for all the plots (Table 5). Differences in the results are due to the slope factor for each one of the different inclinations, and for the cropping factor obtained from the percentage of existing cover crop, ${ }^{14}$ interpolated in Table 6 taking into account the vegetative cover percentage in each plot. This table shows that more crop cover implies less soil loss.

Relative soil loss for the $2: 1$ side slope is shown on the righthand side of Fig. 5 for each treatment. Relative soil loss is the ratio of the soil loss for a particular treatment within an experimental plot to that of the base treatment. Fig. 5 and Table 7 show that the largest soil loss was for the base treatment (plot 21Base), with 71.57 t/ha per year, and the smallest soil loss was for the treatment with a compost dosage of $80 \mathrm{t} /$ ha (plot 21C080), with 46.85 t/ha per year.

Relative soil loss for the $3: 2$ side slope is shown on the righthand side of Fig. 6 for each treatment. This figure and Table 7 show that the largest soil loss was for the base treatment (plot 21Base), with 70.51 t/ha per year, and the smallest soil loss was for the treatment with a sludge dosage of $60 \mathrm{t} /$ ha (plot 32S060), with $9.93 \mathrm{t} /$ ha per year.
Figures 5 and 6 show that these treatments were more effective on the $3: 2$ side slope, with an average soil loss reduction of $47 \%$, than on the $2: 1$ side slope, with an average soil loss reduction of 21\%. For the $2: 1$ side slope plots, sludge treatments presented soil loss reductions between 26\% (plot $21 \mathrm{~S} 100$ ) and 7\% (plot 21S080), and compost treatments presented soil loss reductions between 35\% (plot 21C080) and 15\% (plot 21C060). For the $3: 2$ side slope plots, sludge treatments presented soil loss reductions between $86 \%$ (plot 32S060) and 16\% (plot 32S080), and compost treatments presented soil loss reductions between 62\% (plot 32C040) and 31\% (plot 32C080).

\section{COST ANALYSIS}

The sludge and compost application costs were calculated and compared with the standard costs of road embankment revegetation.

Table 8 shows the costs for sludge and compost application in a road embankment in euros per dry metric tonne. Transport costs, water for irrigation and manipulation are the same for both materials. Sludge also incurs a dehydration cost, though it could also be applied in its liquid form. Sludge is free because it is a required product at the end of treatment lines. In order to establish transport costs an average distance of $40 \mathrm{~km}$ has been supposed.

Taking all these factors into account, sludge has an average gross cost of $€ 246 \cdot 13$ per dry metric tonne, whereas compost has a gross cost of $€ 66 \cdot 80$ per dry metric tonne. However, using these products in road embankments saves society money thanks to dumping reduction. If these savings are deducted from the costs outlined above, the net cost for the

\begin{tabular}{|lccccc|}
\hline$R$ & $K$ & $L$ & \multicolumn{2}{c}{$S$} & $P$ \\
\cline { 3 - 5 } & & & Slope 2:1 & Slope 3:2 & \\
\hline $51 \cdot 10$ & 0.3362 & 0.41 & 18.57 & 31.96 & 0.90 \\
\hline \multicolumn{2}{l}{ Table 5. Factors $R, K, L, S$ and $P$ for Universal Soil Loss Equation } \\
\hline
\end{tabular}

\begin{tabular}{|lccccc|}
\hline \% cover crop & $C$ & \% cover crop & $C$ & \% cover crop & $C$ \\
\hline 5 & 0.807 & 35 & 0.129 & 65 & 0.017 \\
10 & 0.613 & 40 & 0.086 & 70 & 0.012 \\
15 & 0.466 & 45 & 0.065 & 75 & 0.009 \\
20 & 0.319 & 50 & 0.045 & 80 & 0.006 \\
25 & 0.242 & 55 & 0.034 & 90 & 0.003 \\
30 & 0.166 & 60 & 0.023 & 100 & 0.001 \\
& & & & \\
\hline
\end{tabular}




\begin{tabular}{|c|c|c|c|}
\hline Plot & $\begin{array}{l}\text { Soil loss: } \\
\text { t/ha per year }\end{array}$ & Plot & $\begin{array}{l}\text { Soil loss: } \\
\text { t/ha per year }\end{array}$ \\
\hline 2IBase & 71.57 & 32Base & $70 \cdot 51$ \\
\hline 215100 & 52.62 & 325100 & 48.42 \\
\hline 215080 & 66.75 & 325080 & 58.96 \\
\hline 215060 & 56.98 & $32 S 060$ & 9.93 \\
\hline $21 \mathrm{C080}$ & $46 \cdot 85$ & $32 C 080$ & 48.83 \\
\hline $21 \mathrm{C060}$ & $60 \cdot 51$ & $32 C 060$ & 29.78 \\
\hline $21 \mathrm{C} 040$ & 57.09 & $32 \mathrm{C} 040$ & $26 \cdot 54$ \\
\hline
\end{tabular}

administration would be $€ 152 \cdot 68$ per dry metric ton for sludge and €39.05 for compost.

Maximum dosages used in the experiment were $100 \mathrm{t} / \mathrm{ha}(24$ dry metric tonnes per hectare) for sludge and $80 \mathrm{t} /$ ha $(75 \cdot 2$ dry metric tonnes per hectare) for compost. This amounts to $€ 3664 /$ ha and $€ 2940 /$ ha for these dosages of sludge and compost, respectively.

Traditional hydroseeding costs $€ 50000 /$ ha, and includes a mixture of the following components: water (20-40 $\left.\mathrm{m}^{3} / \mathrm{ha}\right)$, seeds (150 kg/ha), straw mulch (1.5-2 t/ha), fertilisers and chemical stabilisers $(200 \mathrm{~kg} / \mathrm{ha})$.

Table 9 compares the average cost of this standard treatment and its repercussions in the road budget with the cost of treatment in which sludge and compost are used. As can be seen, seeds are the most expensive item of the budget.

Comparing with traditional methods costing $€ 50000 /$ ha (4\% of the road's total budget), treatment with only sludge or compost would cost about $€ 3000 /$ ha ( $0 \cdot 24 \%$ of the road's total budget).

\section{SUMMARY, CONCLUSIONS AND RECOMMENDATIONS}

A few years ago sludge and compost were not considered suitable materials for embankment surface treatment to prevent slope erosion. In Europe neither of them has been used for this application; they have been used for agricultural purposes only. ${ }^{12,13}$ In the USA there is some experience of compost usage for reducing runoff and erosion in highway embankments, ${ }^{6,14-16}$ but sludge has not yet been used.

This research shows that the surface application of both products on road embankments increases crop cover. On a $2: 1$ side slope the results of compost treatments (up to 54\% on average) are better than those of sludge treatments (up to $30 \%$ on average), but on a $3: 2$ side slope both results are similar (over 50\% in both cases). Thus both compost and sludge applications are effective erosion control aids that increase the chances of successful vegetation establishment. Sufficient vegetal cover can be obtained with low seed dosages.

This increase in vegetative cover has a direct effect on erosion reduction in the embankment. The treatments tested present an average soil loss reduction of $47 \%$ for the $3: 2$ side slope and 21\% for $2: 1$ side slope. Given the positive results obtained, the use of these products in road embankments must be encouraged, especially on embankments with steep slopes where erosion problems are more important and the treatment results are better.

As mentioned previously, vegetation establishment is the final phase of any roadway construction project, and budgetary constraints are often reflected in embankments revegetation. As the cost of including these recycled materials without vegetal species is very low $(0 \cdot 24 \%$ of the road's total budget), the application of sludge or compost should always be imposed by including them in construction project documentation, even if it is not possible to apply seeds.

The implementation of these measures by clients would help to reach acceptable levels of sustainable development in our society, and this would also include obtaining more durable roads with higher landscape value and less soil loss.

As this would be an innovative application in Europe, there is currently no specific set of regulations. Limits on heavy metal content and microbiological parameters used as a reference for sludge and compost are in accordance with the agricultural standards, regulations that should be more restrictive than for the application suggested. Standards have to be set in relation to treatment processes, number of pathogens (such as E. coli), content of nutrients, and organic contaminants. Therefore it

\begin{tabular}{|c|c|c|}
\hline & $\begin{array}{l}\text { Sludge: } € / d r y \\
\text { metric tonne }\end{array}$ & $\begin{array}{l}\text { Compost: } € / d r y \\
\text { metric tonne }\end{array}$ \\
\hline Dehydrating & $94 \cdot 11$ & -* \\
\hline Buy at fabrication premises & $-*$ & 18.00 \\
\hline Transport & $16 \cdot 60$ & $4 \cdot 25$ \\
\hline Irrigating water & $31 \cdot 25$ & $31 \cdot 25$ \\
\hline Manipulation & $104 \cdot 17$ & $13 \cdot 30$ \\
\hline Total (gross cost) & $246 \cdot 13$ & $66 \cdot 80$ \\
\hline Savings due to reduction in dumping costst & 93.45 & $27 \cdot 75$ \\
\hline Total (net cost) & $152 \cdot 68$ & 39.05 \\
\hline \multicolumn{3}{|c|}{$\begin{array}{l}\text { * Data not applicable. } \\
\text { † Cost of dumping in dumping site }=12 € / \mathrm{m}^{3} \text {. Sludge }\left(\text { density }=0.535 \mathrm{t} / \mathrm{m}^{3} \text {, moisture content }\right. \\
76 \% \text { ). Compost (density }=0.46 \mathrm{t} / \mathrm{m}^{3} \text {, moisture content }=6 \% \text { ). }\end{array}$} \\
\hline
\end{tabular}




\begin{tabular}{|lcc|}
\hline Treatment & $\begin{array}{c}\text { Cost: } \\
€ / \text { ha }\end{array}$ & $\begin{array}{c}\text { Road budget: } \\
\%\end{array}$ \\
\hline A $\quad \begin{array}{l}\text { Traditional hydroseed } \\
\text { Seeds: } 150 \mathrm{~kg} / \mathrm{ha}\end{array}$ & 50000 & 4.00 \\
$\mathrm{~B} \quad \begin{array}{l}\text { Low-cost hydroseed } \\
\text { Seeds: } 50 \mathrm{~kg} / \mathrm{ha}\end{array}$ & 18664 & 1.49 \\
$\mathrm{C} \quad \begin{array}{l}\text { Sludge: } 100 \mathrm{t} / \mathrm{ha} \\
\text { Sludge only }\end{array}$ & 3664 & 0.29 \\
$\mathrm{D} \quad \begin{array}{l}\text { Sludge: } 100 \mathrm{t} / \mathrm{ha} \\
\text { Compost only } \\
\text { Compost: } 80 \mathrm{t} / \mathrm{ha}\end{array}$ & 2940 & 0.24 \\
\hline Table 9. Costs of different road embankment treatments
\end{tabular}

can be said that this application does not represent any threat to public health.

The positive results obtained for sludge and compost application have encouraged new research. Mixtures of both products are now being tested. The experiment is carried out under the same conditions and using the same variables. The preliminary results are much more promising.

\section{I0. ACKNOWLEDGEMENTS}

The research team would like to thank Dr Antonio López Navarro for his personal contribution to this project.

\section{REFERENCES}

1. WORLD COMMISSION ON ENVIRONMENT AND DEVELOPMENT (WCED). Our Common Future (The Brundtland Report). Oxford University Press, Oxford, 1987.

2. European Commission. 2003 Environment Policy Review. Commission of the European Communities, Brussels, 2003.

3. Coppin N. J. and RichardS I. G. (eds). Use of Vegetation in Civil Engineering, CIRIA Water Engineering Report. Butterworths, London, 1990.

4. GRACE J. M. Erosion control techniques on forest road cutslopes and fillslopes in north Alabama. Transportation Research Record, No. 1652, TRB, National Research Council, Washington, DC, 1999, pp. 227-324.

5. ARrAnZ J. C. Ingeniería de diseño y tecnologías para la mitigación de la erosión en taludes excavados. $1^{\text {a }}$ Bienal Española de Ingeniería Geológica y Minera. Instituto Geológico y Minera de España, Madrid, 1991, pp. 43-64.

6. Storey B. B., McFalls J. A. and Godfrey S. H. The Use of Compost and Shredded Brush on Rights-of-Way for Erosion Control. Texas Transportation Institute, College Station, TX, 1996, Research Report 1352-2F.

7. MeYer L. D., WischmeIeR W. H. and Daniel W. H. Erosion, runoff, and revegetation of denuded construction sites. Transaction of the ASAE, 1971, 24, No. 6, 1472-1475.
8. Cameron K. C., Di H. J. and Mclaren R. G. Is soil an appropriate dumping ground for our wastes? Australian Journal of Soil Research, 1997, 35, No. 5, 995-1035.

9. Belmonte A. F. Reutilización y reciclado de materiales. Experiencia en Andalucía. Actas del III Congreso Andaluz de Carreteras Assocación Española de la Carretera, Madrid, 2003, pp. 143-185.

10. RuIZ A. Experiencias en España con la utilización de residuos y de materiales secundarios en carreteras.

Carreteras, 2001, 18, No. 118, 8-25.

11. VipUlanANDAN C., BASHEER M. and O'NeILl M. W. Recycled Materials in Embankments, Except Glass. Preliminary Report. The Center for Innovative Grouting Materials and Technology, Houston, TX, 1996, Research Report 0-1351.

12. AndReAdAKIS A. D., Mamais D., GavalaKi E. and KAMPYLAFKA S. Sludge utilisation in agriculture: possibilities and prospects in Greece. Water Science and Technology, 2002, 46, No. 10, 231-238.

13. Aziz M. A. and KoE L. C. C. Potential utilization of sewagesludge. Water Science and Technology, 1990, 22, No. 12, 277-285.

14. BLOCK D. Controlling erosion from highway projects. Biocycle, 2000, 41, No. 1, 59-62.

15. Persyn R. A., Glanville T. D., Richard T. L., Laflen J. M. and DiXON P. M. Environmental effects of applying composted organics to new highway embankments: Part 1. Interrill runoff and erosion. Transactions of the ASAE, 2004, 47, No. 2, 463-469.

16. Benick S. R., Wilson B. N., Biesboer D. D., HANSen B. and STENLUND D. Performance of erosion control products on a highway embankment. Transactions of the ASAE, 2003, 46, No. 4, 1113-1119.

17. Ministerio De Fomento. PG-3. Pliego de Prescripciones Técnicas Generales para Obras de Carreteras y Puentes, 1st edn. Ministerio de Fomento, Madrid, 1976.

18. CEC. Council Directive of 12 June 1986 on the protection of the environment, and in particular of the soil, when sewage sludge is used in agriculture (86/278/EEC). Official Journal of the European Communities, 1986, No. L 181/ 6-12.

19. Ministerio de Agricultura, Pesca y Alimentación. Orden de 28 de Mayo de 1998 sobre fertilizantes y afines (Transposed European Legislation). Ministerio de Agricultura, Pesca y Alimentación, Madrid, 1998.

20. US DePARTMENT OF Agriculture. Agriculture Handbook 282. US Department of Agriculture, Washington, DC, 1958.

21. Food And Agriculture Organisation. Guidelines for Soil Profile Description, 3rd edn. FA0, Rome, 1990.

22. GonzAlez M. La Ecuación Universal de Pérdidas de Suelo. Pasado, presente y futuro. Ecología, 1991, 5, 7-28.

23. ICONA. Agresividad de la lluvia en España. Valores del Factor R de la Ecuación Universal de Pérdidas de Suelo. ICONA, Madrid, 1988.

\section{What do you think?}

To comment on this paper, please email up to 500 words to the editor at journals@ice.org.uk

Proceedings journals rely entirely on contributions sent in by civil engineers and related professionals, academics and students. Papers should be 2000-5000 words long, with adequate illustrations and references. Please visit www.thomastelford.com/journals for author guidelines and further details. 